\title{
Lokalitas Tafsir Al-Qur'an Minangkabau (Studi Tafsir Minangkabau Abad ke-20)
}

(Locality of Minangkabau in Interpretation of the Qur'an: (the study of Minangkabau interpretation of the 20th century))

\author{
Aldomi Putra ${ }^{1}$, Hamdani Anwar ${ }^{2}$, Muhammad Hariyadi $^{3}$ \\ ${ }^{1}$ STAI YASTIS Padang, ${ }^{2}$ UIN Syarif Hidayatullah Jakarta, ${ }^{3}$ Institut PTIQ Jakarta \\ 1aldo_862000@yahoo.com, ${ }^{2}$ hamdani.anwar@uinjkt.ac.id, ${ }^{3}$ m.hariyadi@ptiq.ac.id
}

DOI: $10.29240 /$ alquds.v5i1.2550

Submitted: 2021-02-27 | Revised: 2021-05-01 | Accepted: 2021-05-11

\begin{abstract}
This study aims to find the absorption of locality in the interpretation of the Qur'an in Minangkabau, and to prove that Anthony H. Johns 'statement "cannot be denied the influence of local language in explaining the Al-Qur'an" and Islah Gusmian's statement "tafsir Al-Qur'an as a cultural product, it certainly struggles with tradition, culture, and socio-political realities". This research is a qualitative research type of library research (library research), which uses a historical-philosophical approach. The primary sources of this research are the interpretation of Tafsir al-Burhân by Haji Abdul Karim Amarullah, Risâlah al-Qaul al-Bayyân fî̀ Tafsîr al-Qur'ân, the work of Syeikh Sulaiman Arrasuli, and the tafsir of al-Da'wah wa al-Irsyâd ilâ Sabîl al -Rasyad by Abdul Lathif Syakur. This research found several aspects of locality in the interpretation of the AlQur'an Minangkabau, namely; first, the writing of interpretation as a request from the community, second, the absorption of local languages in translating and interpreting the Qur'an, third, using local samples in interpretation, fourth, the absorption of local customs in interpretation, and fifth using Minangkabau adagium in interpretation. Thus, the Minangkabau tafsir al-Qur'an is full of locality absorption.
\end{abstract}

Keywords: Locality, Interpretation, Minangkabau

Abstrak. Penelitian ini bertujuan untuk menemukan serapan lokalitas dalam tafsir AlQur'an di Minangkabau, dan membuktikan pernyataan Anthony H. Johns "tidak dapat dinafikan adanya pengaruh bahasa lokal dalam menjelaskan Al-Qur'an" dan pernyataan Islah Gusmian "tafsir Al-Qur'an sebagai produk budaya tentu bergumul dengan tradisi, kultur, dan realitas sosial politik". Penelitian ini merupakan penelitian kualitatif dengan jenis penelitian kepustakaan (library research), yang menggunakan pendekatan historicalfilosofis. Sumber primer penelitian ini adalah tafsir Tafsir al-Burhân karya Haji Abdul Karim Amarullah, Risâlah al-Qaul al-Bayyân fî Tafsîr al-Qur'ân, karya Syeikh Sulaiman Arrasuli, dan tafsir al-Da'wah wa al-Irsyâd ilâ Sabîl al-Rasyâd karya Abdul Lathif Syakur. Penelitian ini menemukan beberapa serapan aspek lokalitas dalam tafsir Al-Qur'an Minangkabau, yaitu; pertama, penulisan tafsir sebagai permintaan masyarakat, kedua, 
keterserapan bahasa lokal dalam menerjemahkan dan menafsirkan Al-Qur'an, ketiga, menggunakan sampel lokal dalam penafsiran, keempat, serapan kebiasaan lokal dalam penafsiran, dan kelima menggunakan adagium Minangkabau dalam penafsiran. Dengan demikian, maka afsir al-Qur'an Minangkabau sarat akan serapan lokalitas.

Kata kunci: Lokalitas, Tafsir, Minangkabau

\section{Pendahuluan}

Anthony H. Johns dalam Qur'anic exegesis in the Malay-Indonesian World: an Introduction survey, ${ }^{1}$ menyatakan bahwa tidak dapat dinafikan adanya pengaruh bahasa lokal dalam menjelaskan Al-Qur'an. Disamping itu nuansa lokal juga telah mewarnai berbagai tafsir Al-Qur'an, baik tafsir-tafsir yang berasal dari timur tengah, begitu juga dengan tafsir-tafsir yang ditulis oleh ulama Nusantara. Di Nusantara misalnya penulisan kitab tafsir dengan menggunakan symbollokal dalam bentuk tulisan Arab Pegon, ${ }^{2}$ ataupun latin. ${ }^{3}$ Di samping itu, budaya serta dialektika budaya dan pemikiran di suatu tempat juga menjadi pengaruh tersendiri.

Islah Gusmian menyatakan bahwa tafsir Al-Qur'an sebagai produk budaya tentu bergumul dengan tradisi, kultur, dan realitas sosial politik dimana ia ditulis oleh pengarangnya, hal serupa terjadi dalam penulisan tafsir di Indonesia. ${ }^{4}$ Lebih lanjut Islah menyebutkan hal seperti itu terlihat dalam pemakaian bahasa, aksara, serta isu sosial, politik, dan ideologi yang dikontestasikan. Dalam dinamika penulisan tafsir di Nusantara ditemukan tafsir ditulis dalam berbagai bahasa, seperti bahasa Arab yang ditulis oleh Syeikh an-Nawâwî al-Bantanî (1813-1897 M) dengan karyanya Marah Labib dan Djalaluddin Thaib dengan karyanya Tafsîr

${ }^{1}$ Anthony H. Jhons, Qur'anic exegesis in the Malay-Indonesian World: an Introduction survey dalam Abdullah Saeed (ed), Approac to the qur'an in contemporary Indonseia, New York: Oxford University Press, 2006. Lihat juga Anthony H. Jhons tentang Quranic Exegesis in Malay World: in Search of a frofile dalam Anrew Rippin, (ed), approach to the bistory of the interpretation of the Quran, Oxpord: Clarendon House, 1998. Lihat juga Hamka Hasan, Pemetaan tafsir di Indonesia (19902000) Jurnal Studi Alqur'an, Vol.I, No. 3, 2006, 521-542.

${ }^{2}$ Arab pegon dalam penulisan merupakan sebuah tradisi tulis-menulis dikalangan intelektual pensanteren, ketika menuliskan karya intelektualnya dalam bahsa lokal. Ahmad Baidowi, Tafsir Al-Iklīl fī Ma’ânī Al-Tanzịl Karya Kh Mishbah Musthafa, Jurnal Nun, Vol. 1, No. $1,2015,44$

Ahmad Zaiyadi, Dinamika Studi al-Qur'an di Indonesia, https://issuu.com/jurnalalbayanstiq/docs/1.zaiyadi, diakses pada tanggal 30/10/2018

${ }^{4}$ Islah Gusmian, Tafsir al-Qur'an Bahasa Jawa Pengukuhan Identitas, ideology, dan Politik, Jurnal Subuf, Vol.9.No. 1., Jun 2016, hlm. 141-168. Issn 1979-6544: eISSN 23561610;http://jurnalsuhuf.kemenag.go.id.

5 Syeikh Nawâwî al-Bantanî al-Jawî mempunyai nama asli Nawawi bin Umar bin 'Arabi. Ia lahir di desa Tanara, Tirtayasa, Serang, Banten (sekarang provinsi yang pisah dari Jawa Barat) pada tahun $1230 \mathrm{H} / 1813$ M. Beliau wafat pada hari Kamis 25 Syawal 1314 H/1897 M di Syi'ib Ali, Mekkah dalam 
al-Munir, dalam bahasa Arab Melayu seperti yang ditulis oleh Syeikh Abdur Rauf al-Singkil (1615-1693 M) dengan karyanya Turjumân al-Mustafid, Haji Abdul Karim Amrullah(1879-1945 M) dengan karyanya al-Buhân, dan Risâlab al-Qaul al-Bayân fì Tafsîr al-Qur'ân oleh Syeikh Sulaiman Arrasuli (1871-1970), dalam bahasa Jawa seperti yang ditulis oleh K.H. Muhammad Sâlîh bin 'Umar as-Samaranî (18201903) ia menulis Faid ar-Rabmân fî Turjumâh Kalâm Mâlik ad-Dayyân, Mahmud Yunus(1899-1982) menulis terjemahan Al-Qur'an ke dalam bahasa Indonesia dengan menggunakan tulisan Arab melayu.

Di Minangkabau tradisi menulis tafsir juga berkembang semenjak awal abad 20. Tercatat ada beberapa kitab tafsir yang ditulis oleh ulama Minangkabau yaitu; Tafsîr al-Burbân ${ }^{6}$ oleh Haji Abdul Karim Amrullah (1879-1945 M), Risalab alQaul al-Bayân fî Tafsîr al-Qur'ân oleh Syeikh Sulaiman Arrasuli (1871-1970), AlDa'wah wa al-Irsyâd ilâ Sabîl al-Rasyâd(Tafsir wa Minan Nas) oleh Abdul Lathif Syakur (1882-1963), Tafsir al-Munir oleh Djalaluddin Thaib (1895-1959M), Tafsir al-Quran al-Karim oleh Mahmud Yunus (1899-1982), Tafsir al-Azhar Karya Hamka (19081981), dan masih ada karya lainnya yang belum terpublikasi. Seperti yang dijelaskan oleh Islah di atas patut diduga bahwa penulisan kitab tafsir di Minangkabau juga tidak luput dari pergumulan dengan tradisi, kultur, dan realitas sosial masyarakat Minangkabau. Di samping itu perdebatan ideologis dan akademik di Minangkabau juga akan berpengaruh pada penulisan karya tafsir. Jika diamati lebih lanjut dalam konteks kesejarahan Islam di Indonesia tentu akan ditemui aspek lokalitas dalam pengembangan ajaran Islam di bumi Nusantara ini. Nelly van Doorn-Harder mencatat dalam tulisannya 'Southeast Asia' bahwa di Indonesia Sunan Kalijaga dalam mengembangkan Islam menggunakan praktik

usia 84 tahun. Ansor Bahary, Tafsir Nusantara: Studi Kritis Terhadap Marah Labid Nawawi al Bantani, Jurnal Ulul Albab Volume 16, No.2 Tahun 2015.

${ }^{6}$ Tafsî̀ Al-Burbân, Bukittinggi: Dar Fikr "Baru" Fort De Kock, 1927. Pencantuman penerbit dan tahun terbit sekaligus mengkritik data yang disebutkan oleh Rifa Roifa,dkk, dengan judul tulisan Perkembangan tafsir di Indonesia (pra Kemerdekaan 1900-1945), di dalam pendahuluannya disebutkan "karya literature tafsir yang berkonsentrasi pada juz-juz tertentu dengan muncul hanya juz 30 (juz amma) yang menjadi objek tafsir, didalam contohnya ia menuliskan al-Burhân Tafsir Juz Amma (padang: al-Munir, 1922)" dari buku yang penulis dapatkan judul tafsirnya al-Burhân, keterangan yang diberikan oleh Haji Abdul Karim Amarullah dalam muqaddimahnya ia hanya menafsirkan dua puluh ayat saja yang dimulai dari surat al-Dhuha sampai an-Nâs, dan bukunya di terbitkan di Bukittinggi bukan di padang, penerbitnya Dar Fikr "Baru" Fort De Kock, 1927, bukan tahun 1922 seperti yang disebutkan., namun demikan data lain seperti yang dikemukakan oleh Akhria Nazwar ketika menyebutkan karya-karya Haji Abdul Karim Amrullah, ia menuliskan kitab al-Burhân terbit tahun 1922, akan tetapi ia tidak menyebutkan tempat terbit dan penerbitnya. Lihat Akhria Nazwar, Syekh Abmad Khatib Ilmuan Islam di Permulaan Abad Ini, Jakarta: Pustaka Panjimas, 1983, 72. 
lokal. ${ }^{7}$ Praktik lokal menjadi instrumen untuk mentransfer ajaran Islam pada umat.

Kitab-kitab tafsir karya ulama Minangkabau yang telah disebutkan di atas sangat penting untuk diteliti, terutama karya Haji Abdul Karim Amrullah (18791945 M), Syeikh Sulaiman Arrasuli (1871-1970), dan Syeikh Abdul Lathif Syakur (1882-1963), mengingat ketiga ulama tersebut memiliki peran besar dalam khazanah tafsir lokal Minangkabau. Di samping itu meneliti karya tafsir Al-Qur'an di Minangkabau sangat penting, menimbang keberadaan tafsir di Minangkabau diiringi oleh berbagai perdebatan lokal di antaranya perdebatan antara ulama Kaum Tua dan Ulama Kaum Muda. ${ }^{8}$ Kaum Muda dalam hal ini tercermin pada sosok Haji Abdul Karim Amrullah (1879-1945 M) dan Kaum Tua yang melekat pada Syeikh Sulaiman Arrasuli (1871-1970 M). Kedua-duanya sama-sama memiliki karya tafsir. Hal yang menarik menjadi pertanyaan adalah apakah penulisan tafsir dan gagasan dalam kitab tafsir keduanya terpengaruh oleh pergumulan dan perdebatan yang terjadi antara kedua kubu tersebut? Di samping itu Abdul Lathif Syakur (1882-1963) berada di antara dua posisi tersebut, kendatipun polemik khilafiah sedang hangat di kalangan Kaum Tua dan Kaum Muda tersebut. ${ }^{9}$

Tafsir Al-Qur'an di Minangkabau seperti Risâlah al-Qaul al-Bayân fi Tafsîr al-qur'ân karya Syeikh Sulaiman Arrasuli (1871-1970) ${ }^{10}$ dari hasil pengamatan penulis apabila dilihat dari sisi corak (laun) tafsir, menggunakan al-Adab wa alIjtima' hal ini menjadi indikator kuat, bahwa dalam penulisan kitab tafsir di Minangkabau sangat mementingkan dan mengakomodir lokalitas dalam

${ }^{7}$ Sunan kalijaga introduced the method of infusing local customs and practices with islam, which provided a model of peaceful religious transmission. He used local practices and culture such as the shadow puppet theater (wayang) and the salamatan, a ceremonial communal meal of reconciliation to gradually convert the population to Islam (Sunan Kalijaga memperkenalkan metode menanamkan adat istiadat setempat dan praktik dengan islam, yang menyediakan model transmisi agama damai. Dia menggunakan praktik dan budaya lokal seperti teater boneka wayang (wayang) dan salamatan, makanan bersama untuk rekonsiliasi secara berangsur-angsur mengubah populasi menjadi Islam.) Nelly van Doorn-Harder, Southeast Asia dalam Andrew Rippin (ed) The Islamic World, London \& New York: Routledge, 2010, 105.

${ }^{8}$ Ulama Kaum Tua disebut sebagai aliran pemikiran konservatif, ortodoks, dan tradisionalis. Nasrullah, Respons Dan Tantangan Kaum Tua Atas Kritik Kaum Muda Terhadap Tarekat Di Minangkabau Awal Abad 20, Jurnal 'Anil Islam Vol. 9. Nomor 2, Desember 2016 , 212-246. Sedangkan kaum Muda adalah sekelompok ulama yang berfikiran modern dan progresif.

${ }^{9}$ Ridhoul Wahidi, Tafsir Yâ Ayyuha a al-LaŻina âmanū Karya Syaikh Abdul Latif Syakur 1882-1963 (sunting teks dan analisis Isi), Disertasi Pascasarjana UIN Walisongo, tahun 2018. 106.

${ }^{10}$ Syeikh Sulaiman Arrasuli lahir di Canduang Kecamatan IV Angat, Kabupaten Agam (lebih kurang $10 \mathrm{Km}$ arat Timur Kodya Bukittinggi) pada tanggal 10 Desember $1871 \mathrm{M} /$ Bulan Muharram 1297 H. Anak dari Angku Mudo Muhammad Rasul, seorang ulama yang mengajar di Surau Tangah Canduang, sedangkan Ibu beliau adalah Siti Buliah, suku Caniago, seorang wanita yang taat beragama dan menjunjung tinggi adat istiadat yang luhur.(Yusran Ilyas:1995:4) 
penafsirannya. Syeikh Sulaiman Arrasuli (1871-1970) di samping menulis kitab tafsir, ia juga menulis buku tentang Pertalian Adat Dan Sayar,, ${ }^{11}$ yang banyak diperbincangkan dalam buku tersebut adalah tentang Adat Basandi Syara', Syara' Basandi Kitabullah. Oleh karenanya patut diduga bahwa kitab tafsirnya juga terpengaruh oleh karyanya tersebut, mengingat Syeikh Sulaiman Arrasuli (18711970) sedang melakukan usaha dengan mempertalikan atau menghubungkan antara adat dan syarak di Minangkabau. Hal ini terlihat ketika Syeikh Sulaiman Arrasuli menafsirkan surat al-Ma'un/107:2:

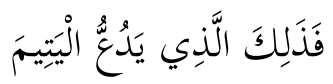

Artiny a bermula orang itu ialah orang yang menolak akan anak yatim, seorang kanakkanak yang kematian bapak, sekalipun ada baginya ibu, bukan seperti yatim binatang, yaitu anak binatang yang tidak ada ibu bapaknya -menolak yatim-aniaya kepadanya dengan mengambil baknya, seperti harta peninggalan bapaknya dan lain-lain seperti yang berlaku di Minangkabau, atau menyurub anak-anak itu pada sekalian pekerjaan yang bukan kerjanya atau meninggalkan menolongnya dengan menghilangkan manfaat baginya dan menolak. mudarat dari padanya...Wallabu 'alam. ${ }^{12}$

Sampel penafsiran di atas dapat dipahami, bahwa Syeikh Sulaiman Arrasuli (1871-1970) dalam menafsirkan ayat tersebut memperhatikan konteks lokal di Minangkabau. Ia menerangkan tafsiran ayat dengan perbuatan yang biasa terjadi di Minangkabau dalam hal ini adalah perlakuan orang Minang terhadap anak yatim. Penafsiran yang ia praktikkan sangat memperhatikan aspek lokalitas.

Haji Abdul Karim Amrullah (1879-1945 M) dalam muqaddimab ${ }^{13}$ tafsirnya mengatakan bahwa kitab tafsirnya ini merupakan hasil dari khotbah dan ceramah beliau di Surau Jembatan Basi Padang Panjang, dan penulisannya dalam rangka memenuhi permintaan murid-muridnya. Dari pernyataan tersebut penulis melihat bahwa Haji Abdul Karim Amrullah merespons permintaan para muridnya, serta menuliskan kitab tafsir. Dalam kitabnya Haji Abdul Karim Amrullah hanya menafsirkan dua puluh surat pada juz. 'Amma yang dimulainya dari surat ad-Dhuba sampai akhir surat al-Nâs. Ungkapan beliau yang mengatakan bahwa tafsirnya merupakan hasil ceramah rutin yang dilakukan di Surau Jembatan Basi Padang Panjang, menunjukkan bahwa penafsiran beliau tidak terlepas dari persoalan yang dihadapi oleh masyarakat lokal, mengingat Abdul Karim Amrullah berada di

\footnotetext{
${ }^{11}$ Syeikh Sulaiman Arrasuli, Pertalian Adat \& Syara' (alih bahasa oleh Hamdan Izmy), Ciputat: Ciputat Press, 2003.

${ }^{12}$ Syeikh Sulaiman Arrasuli, Risâlah al-Qaul al-Bayân fî̀ Tafsîr al-Qur'ân, Bukittinggi: Fort de Kock, 1928, 115

${ }^{13}$ Haji Abdul Karim Amarullah, al-Burân, Bukittinggi: Dar Fikr "Baru” Fort De Kock, 1927, 15-16.
} 
lingkungan masyarakat yang beliau setting sebagai masyarakat modern (Kaum Muda). Oleh karenanya perlu untuk diteliti lebih lanjut tentang hal tersebut.

Berbeda dengan Syeikh Sulaiman Arrasuli dan Haji Abdul Karim Amrullah, Abdul Lathif Syakur menulis berbagai tafsir, di antaranya: Al-Da'wah wa al-Irsyâd ilâ Sabîl al-Rasyâd kitab ini menjelaskan penafsiran ayat-ayat yang diawali dengan kata wa min an-Nâs, jumlah ayat yang dikumpulkannya sebanyak 13 ayat. ${ }^{14}$ Tafsîr Mufradâd al-Qur'an Q.S. al-Baqarah. Tujumah Tafsîr Lafiziyah kitab ini menjelaskan tafsir dari surat al-Fâtihah, yang ditulis dengan menggunakan bahasa Arab Melayu. Tafsir Surah Al-Mukminûn, kitab ini ditulis menggunakan bahasa Arab, dan tafsir Yâ Ayyuba al-Lażina âmanû semua kitab tafsir tersebut masih dalam bentuk naskah sebagaimana ditemukan oleh Ridhoul Wahidi dalam penelitian penelitiannya. ${ }^{15}$ Kecuali Al-Da'wah wa al-Irsyâd ilâ Sabîl al-Rasyâd, kitab ini telah diterbitkan pada tahun 1951 di Bukittinggi. Dalam penelitian penelitian ini, penulis membatasi diri dari karya Abdul Lathif Syakur tentang tafsir, yakni kitab Al-Da'wah wa al-Irsyâad ilâ Sabîl al-Rasyâd, alasan penulis karena kitab ini sudah dicetak. Disamping itu penafsirannya tentang ayat-ayat yang di awali oleh wa min al-Nâs membuat bentuk tafsirnya berbeda dari mufasir lainnya. Sajian tafsir yang ke tengahkan oleh Abdul Lathif Syakur menunjukkan sebuah tawaran baru kepada masyarakat muslim khususnya Minangkabau untuk mendekati dan menelaah AlQur'an melalui pendekatan tematik yang mengkhususkan pada frase wa min alNâs. Oleh karenanya perlu ditelusuri kitab tafsirnya lebih lanjut, sehingga dapat dibuktikan apakah Abdul Lathif Syakur mengakomodir aspek lokalitas dalam penafsirannya yang bercorak tematik tersebut?

Pentingnya penelitian ini adalah untuk mengungkap lokalitas tafsir AlQur'an di Minangkabau. Di samping itu secara teoritis penelitian ini membuktikan pengaruh lokalitas terhadap sebuah penafsiran sudah semestinya ditelaah secara bolistic. Sudah jamak diketahui bahwa setiap mufasir akan mempertimbangkan aspek lokalitas di mana mufasir itu menulis karyanya.

Penelitian ini berbeda dengan penelitian yang dilakukan oleh penelitipeneliti terdahulu, seperti Irwani 16 dengan judul Corak Tafsir Ijtimầ̂ dalam Karya-Karya dan Pemikiran Keagamaan Syekh Sulaiman Arrasuli (1871-1970), Halimatusa'diyah dengan judul "Karakteristik Tafsir di Indonesia: Analisis Kritis Terhadap Tafsir Juz 'Amma Risâlah Al-Qaul Al-Bayân dan Kitab Al-Burhân”.17

${ }^{14}$ Abul Latif Syakur, Al-Da'wah wa al-Irsyâd ilâ Sabil al-Rasyâd, Ford de Kokc Bukittinggi: Penerbit Tsamaratul Ikhwan, 1951.

${ }^{15}$ Ridhoul Wahidi, Tafsir Yâ Ayyuha a al-LaŻina âmanū Karya Syaikh Abdul Latif Syakur 1882-1963 (sunting teks dan analisis Isi), Disertasi Pascasarjana UIN Walisongo, tahun 2018.

${ }^{16}$ Irwani, Corak Tafsir Ijtimâ'̄̄ dalam Karya-Karya dan Pemikiran Keagamaan Syekh Sulaiman Arrasuli (1871-1970), Tesis pada Pascasarjana Institut Ilmu al-Qur'an (IIQ) Jakarta, 2019.

${ }^{17}$ Halimatusa'diyah, Karakteristik Tafsir di Indonesia: Analisis Kritis Terhadap Tafsir Juz 'Amma Risalah Al-Qaul Al-Bayan Dan Kitab Al-Burhan, Disertasi pada SPS UIN Jakarta, 2020. 
Zikra Fadila, ia meneliti tentang karya Abdul Lathif Syakur lainnya yaitu tafsir ya Ayyuha an-Nâs yang dikemasnya dalam judul Naskah Tafsî Yâ Ayyuhâ an-Nâs Syekh Abdul Lathif Syakur (1882-1963) Tafsir Kebangsaan dari Ranah Minang. Dalam penelitiannya Zikra memfokuskan bahasannya pada sunting teks dan ideologi Abdul Lathif Syakur dibalik teks tersebut. Dan Ridhoul Wahidi dengan tema Tafsir yâ Ayyuha al-Lażina Âmanû Karya Syekh Abdul Lathif Syakur 18821963 (suntingan teks dan analisis isi).$^{18}$ Dalam penelitiannya ini, Ridhoul Wahidi, menelaah sunting teks dan analisis isi salah satu karya tafsir Abdul Lathif Syakur yakni Tafsir yâ Ayyuha al-Lażîna âmanû, dengan menggunakan pendekatan filologi. Mafri Amir yang berjudul Tafsir Al-Burhân Abdul Karim Amrullah: Studi Analisis Metode dan Corak.19 Dalam penelitiannya Mafri hanya menyentuh metode dan corak Abdul Karim Amrullah dalam tafsirnya secara garis besar.

Ragam penelitian di atas berbeda dengan penelitian yang penulis lakukan, terutama dalam aspek lokalitas yang terserap dalam tafsir Al-Qur'an yang ditulis oleh Haji Abdul Karim Amrullah, Syeikh Suliaman Arrasuli dan Abdul Lathif Syakur.

Dari latar belakang di atas pertanyaan penelitian ini adalah bagaimanakah bentuk lokalitas/serapan lokal dalam tafsir Al-Qur'an Minangkabau? Penelitian ini bertujuan untuk menemukan serapan lokalitas dalam tafsir Al-Qur'an Minangkabau. Untuk menjawab pertanyaan ini, penulis menggunakan metode kualitatif, dengan jenis penelitian kepustakaan, dengan pendekatan historicalfilosofis, mengingat penelitian ini akan membaca kitab-kitab tafsir yang ditulis oleh ulama Minangkabau tanpa menggunakan statistik.

\section{Lokalitas Tafsir Al-Qur'an}

Philip Cook, menyatakan bahwa untuk menjelaskan konsep lokalitas mesti menggunakan epistemologi realis dalam kaitannya dengan sosial. ${ }^{20}$ Artinya membincangkan lokalitas tidak bisa terlepas dari masalah sosial, sehingga bagi Philip Cook dalam pembahasan tentang lokalitas tidak bisa dipisahkan dengan

${ }^{18}$ Ridhoul Wahidi, Tafsir yâ Ayyuha al-Lażīna âmanū Karya Syaikh Abdul Latief Syakur 1882-1963 (Suntingan Teks dan Analisis Isi), Disertasi Program Doktor Studi Islam Pascasarjana Universitas Islam Negeri (UIN) Walisongo Semarang tahun 2018.

${ }^{19}$ Mafri Amir, Tafsir Al-Burbân Abdul Karim Amarullab: Studi Analisis Metode dan Corak, Laporan Penelitian Berbasis Publikasi Nasional Terakreditasi, Jakarta: Universitas Islam Negeri (UIN) Syarif Hidayatullah Jakarta, 2014.

${ }^{20}$ Phipip Cook, Locality, Structure, and Agency: A Theoretical Analysis, Source: Cultural Anthropology, Vol. 5, No. 1 (Feb., 1990), pp. 3-15 Published by: Wiley on behalf of the American Anthropological Association Stable URL: https://www.jstor.org/stable/ 656501 Accessed: 07-022019 02:54 UTC. 
epistemologi realis. Apa yang dikatakan oleh Philip Cook sangat berkaitan dengan pemaknaan lokalitas itu sendiri. Kata lokalitas merupakan derivasi dari kata lokal. Kata lokal dalam Kamus Besar Bahasa Indonesia (KBBI) memiliki beberapa makna, yaitu berarti ruang yang luas, berarti terjadi (berlaku, ada, dan sebagainya) di satu tempat, tidak merata; setempat, berarti di suatu tempat (tentang pembuatan, produksi, tumbuh, hidup, dan sebagainya); setempat. ${ }^{21}$

Kata lokal dalam Collins Dictionary dijelaskan bahwa "Local means existing in or belonging to the area where you live, or to the area that you are talking about". Kata 'lokal' berarti ada di atau milik daerah tempat tinggal anda, atau daerah yang anda bicarakan. Dari definisi tersebut dapat dipahami bahwa kata 'lokal' berarti suatu hal yang berasal dari daerah. Kata lokal juga dipahami dengan 'asli'.

Abrams dalam A Glossary of Literary Terms mendefinisikan kata local dengan representasi terperinci dalam fiksi prosa tentang latar, dialek, adat istiadat, pakaian, dan cara berpikir dan perasaan yang berbeda dari suatu wilayah tertentu. ${ }^{23}$ Dalam bahasa Inggris local berarti tempat sedangkan locality berarti tempat dan sekitarnya. ${ }^{24}$ Di samping itu Abrams juga menyebut istilah warna lokal (local color). Istilah warna lokal sering diterapkan pada karya-karya tertentu. ${ }^{25}$ Pengetahuan lokal adalah pengetahuan yang telah diuji dan terbukti valid dalam konteks lokal dan telah diakumulasikan oleh komunitas lokal atau masyarakat. ${ }^{26}$ Sedangkan kata lokalitas bisa dipahami dengan warna lokal yang seperti yang dipahami oleh Abrams. Lokalitas merupakan manifestasi dari corak atau warna lokal yang memberikan gambaran mengenai latar, dialek, adat istiadat, cara berpakaian, cara merasa, dan lain sebagainya yang khas dari suatu daerah tersebut.

Lokalitas dalam tafsir adalah corak dan warna lokal yang meresepsi sebuah karya tafsir baik berkenaan dengan latar belakang seorang author tafsir, dialek, adat-istiadat, dan pemikiran yang berkembang di daerah seorang author tafsir

${ }^{21}$ Tim Penulis, Kamus Besar Bahasa Indonesia (Jakarta: Balai Pustaka,2002), 680.

${ }^{22} \mathrm{https}$ //Www.collinsdictionary.com/dictionary/english/localdiaksespada19092019.

${ }^{23}$ M.H Abrams, A Glossary of Literary Terms Seventh Edition, United States of Amerika, Publisher: Earl McPeek, 1999, 145-146

${ }^{24}$ John M. Echols dan Hassan Shadily, Kamus Ingris Indonesia, Jakarta: PT Gramedia Pustaka, 2006, cetatakan ke-XXVIII, 363.

${ }^{25}$ Seperti O. Henry atau Damon Runyon yang berlatar di New York City, mengandalkan minat mereka terutama pada sentimental atau representasi komik dari kekhasan permukaan suatu wilayah, alih-alih pada karakteristik dan masalah manusia yang lebih mendalam, kompleks, dan umum. M.H Abrams, A Glossary of Literary Terms Seventh Edition, United States of Amerika, Publisher: Earl McPeek, 1999, 145-146.

${ }^{26}$ Yin Cheong Cheng, Fostering Local Knowledge and Human development in Globalization of Education, The International Journal of Education Management, Volume 18 Number 1-2004. Pp 7-24 Cemerald Group Publishing Limited- ISSN 0951-354X DOI 10.1108/09513540410512109. 9. 
menetap dan juga berkaitan dengan unsur yang berhubungan dengan keadaan atau kondisi di suatu tempat.

Ignaz Goldziher, dalam Mąhab Tafsir Klasike Hingga Modern, menjelaskan secara historis terkait tafsir mulai dari tahap awal tafsir bi al-Ma'tsûr, kemudian berlanjut pada tafsir dalam perspektif atau corak teologi rasional, tafsir dalam perspektif tasawuf, tafsir dalam perspektif sekte keagamaan, dan tafsir dalam era kebangkitan Islam. ${ }^{27}$ Dari semua penjelasannya Ignaz Goldziher terkait hal di atas, sangat dimungkinkan penulisan tafsir Al-Qur'an dipengaruhi oleh lokalitas yang mengitarinya. Hal ini terbukti dalam penjelasannya tentang munculnya tafsir perspektif ideologi, perspektif tasawuf, perspektif figh/ahkam, dan lain sebagainya.

Kemunculan ragam penafsiran juga salah satu bukti bahwa lokalitas memainkan perannya dalam setiap karya tafsir, sehingga boleh jadi contoh kasus dalam sebuah tafsir berbeda dengan kitab tafsir lainnya. Di samping itu perbedaan metode dan corak akan melahirkan perbedaan juga dalam penafsiran. Corak penafsiran adalah hal yang dominan dipengaruhi oleh lokalitasnya. Sebut saja misalnya corak teologi seperti di sebut oleh Ignaz Goldziher di atas, corak tersebut berkembang dalam tafsir karena pada masa lahirnya tafsir-tafsir sepeti karya Zamakhsyarî (467-538) ${ }^{28}$ dan Fakhruddin al-Râzî (544-604) ${ }^{29}$ sedang berkembangnya pemahaman teologi dan derasnya arus dialektika antara kelompok Mu'tazilah dan Asy'ariyah.

Kehadiran karya-karya tafsir di berbagai wilayah seperti wilayah Timur Tengah yang terhimpun padanya berbagai Negara Arab seperti Saudi Arabia, Mesir, Yaman dan sebagainya, membuktikan bahwa tafsir-tafsir tersebut adalah dalam rangka menjelaskan firman Allah SWT kepada penduduk setempat. Begitu juga halnya dengan karya-karya tafsir di luar Arab seperti Nusantara, lahirnya berbagai tafsir Al-Qur'an di Nusantara juga menjadi bukti bahwa tafsir Al-Qur'an menjawab problematik yang dihadapi oleh berbagai masyarakat termasuk masyarakat Indonesia, yang tidak semuanya mengerti dengan bahasa Arab dan tidak semuanya juga mampu untuk menafsirkan Al-Qur'an, ${ }^{30}$ sehingga diperlukan penafsiran terhadap Al-Qur'an dengan menggunakan bahasa yang bisa dimengerti oleh penduduk dimana umat Islam berkembang, Indonesia misalnya melahirkan

${ }^{27}$ Ignaz Goldziher, Maz̧hab Tafsir dari Klasik hingga Modern (terj. M. Alaika Salamullah, dkk), Yogyakarta: Penerbit eLSAQ Press, Cetakan V, 2010.

${ }^{28} \mathrm{Abu}$ al-Qâsim Muhammad Ibn Umar Zamakhsyarî, al-Kasyâf an Haqâiq ghawâmidh alTan₹îl wa 'uyun al-Aqâwil fì wujūh al-Ta'wîl, Riyadh: Maktabah al-'abikân, 1418H/1998. 1401H/1981M.

${ }^{29}$ Fakhruddîn al-Râzî, Tafsir al-Kabîr wa Mafatih al-Ghaib, Libanon: Dâr al-Fikr,

${ }^{30}$ Ahmad Zaiyadi, Lokalitas Tafsir Nusantara:Dinamika Studi al-Qur'an di Indonesia, Makalah, t.th. 8 . 
produk tafsir berbahasa Indonesia seperti tafsir Qur'an Karim karya Mahmud Yunus misalnya ${ }^{31}$ di samping itu ada juga tafsir yang ditulis dengan bahasa daerah seperti tafsir bahasa Sunda dengan judul Qur'an Adzhim ditulis oleh Hasan Mustopa (1852-1930M/1268-1348H). ${ }^{32}$

Dari penjelasan di atas, dapat dipahami bahwa setiap penulisan tafsir $\mathrm{Al}-$ Qur'an tentunya meresepsi lokalitas tempat seorang mufasir itu bermukim, dan atau meresepsi ideologi dan paham yang dianut oleh mufasir tersebut. Hal itu mengingat bahwa penafsiran terhadap Al-Qur'an adalah penyambung dan penyampaian maksud dari firman Allah SWT kepada hamba-Nya.

Berbagai pengaruh dan unsur-unsur lokal yang terdapat dalam sebuah penafsiran, inilah yang penulis maksud dengan lokalitas tafsir dalam penelitian ini. Sehingga dalam penelitian ini penulis akan dapat mengungkap dan menemukan bentuk-bentuk dan unsur-unsur lokal yang terdapat dalam tafsir Al-Qur'an di Minangkabau terutama pada tiga kitab tafsir yang menjadi objek penelitian ini, yaitu tafsir al-Burbân karya Haji Abdul Karim Amrullah, Risâlah al-Qaul al-Bayân karya Syeikh Sulaiman Arrasuli dan ad-Da'wâ wa al-Irsyâ ilâ Sabîl al-Rasyâd karya Abdul Lathif Syakur.

\section{Serapan Lokalitas Tafsir Al-Qur'an Minangkabau}

Penerapan unsur lokalitas yang mengakar dalam khazanah penafsiran akan sangat membantu umat Islam untuk memahami pesan-pesan yang terkandung dalam Al-Qur'an..$^{33}$ Menerapkan dan mengakomodir lokalitas dalam penafsiran akan melestarikan entitas budaya dan dapat merawat sinergitas antara budaya lokal dan Islam. Penerapan unsur-unsur lokal tersebut dalam kajian tafsir Al-Qur'an sudah diterapkan oleh para mufasir terutama mufasir di Indonesia, seperti tafsir al-iklîl fì ma'ânî al-tañîl karya KH. Mishbah Musthafa (L. 1917). ${ }^{34}$ Tafsir ini ditulis dengan menggunakan bahasa Jawa dan aksara pegon. Ahmad Baidowi telah mengungkap aspek-aspek lokalitas yang terkandung dalam tafsir tersebut. ${ }^{35}$

${ }^{31}$ Mahmud Yunus, Tafsir al-Quranul Karim, Jakarta:Pustaka Muhammadiyah, Cetakan ke VII, 1957. Baca juga Nasruddin Baidan, Perkembangan Tafsir Al-Quran di Indonesia, Tiga serangkai, 2002., bias juga ditemukan dalam Howard M.Federspiel, Kajian al-Quran di Indonesia dari Mahmud Yunus bingga Quraish Shibab, Bandung: Mizan, 1994. Lihat juga Islah Gusmian, Khazanah Tafsir di Indonesia dar Hermeneutik bingga Ideologi, Jakarta: Teraju, 2003, $2017,100$.

${ }^{32}$ Jajang A Rohmana, Sejarah Tafsir al-Qur'an di Tatar Sunda, Bandung: Mujahid Press,

${ }^{33}$ Ahmad Baidowi, “Aspek Lokalitas Tafsir al-Iklīl fì Ma’âni al-Tanzịl” dalam Jurnal NUN vol. 1, no. 1 2015, 60.

${ }^{34}$ Tafsir ini terkenal di wilayah Jawa Tengah dan Yogyakarta.

${ }^{35}$ Ia menemukan ada lima aspek lokal dalam tafsir tersebut yaitu; mengkritik tradisi, mengkritik terjemahan lokal, mengkritik MTQ, mengkritik pengkultusan guru, dan mendorong kemajuan. Lihat. Ahmad Baidowi, Aspek Lokalitas Tafsir al-Iklīl fị Ma'âni al-Tanzīl dalam Jurnal NUN vol. 1, no. 1 2015, 60. 
Berikutnya tafsir Al-Qur'an yang kental akan nuansa lokalitasnya adalah tafsir alIbrî karya Bisri Musthafa. Bisri Musthafa menulis tafsirnya dengan menggunakan bahasa Jawa dan Arab-Pegon, ${ }^{36}$ dan tafsir Qur'anul Adhim karya Haji Hasan Musthafa. Tafsir ini di tulis dengan menggunakan bahasa Sunda dengan menggunakan aksara pegon pada awal abad ke $20 .{ }^{37}$ Di Minangkabau tafsir AlQur'an yang berkemungkinan sarat akan lokalitas, seperti Haji Abdul Karim Amrullah dalam tafsir al-Burbân, Syeikh Sulaiman Arrasuli dalam Risalab al-Qaul alBayân fì Tafsìr al-Qur'ân, dan Abdul Lathif Syakur dalam al-Da'wah wa al-Irsyâd ilâ Sabîl al-Rasyâd. Ketiga tafsir tersebut yang akan penulis paparkan aspek lokalitas yang meresapinya.

Tafsir Al-Qur'an di Minangkabau jika dilihat dari sisi corak (laun) tafsir, mayoritas bercorak al-Adab wa al-Ijtima'̌, seperti tiga karya tafsir di atas. Ketiga karya tafsir tersebut menawarkan gagasan tafsir yang mengakomodir lokalitas dan bahkan dalam karya tafsir tersebut akan ditemui kritik dan korelasi antara budaya lokal dengan Islam.

Korelasi dan persentuhan Al-Qur'an dengan budaya lokal Minangkabau akan melahirkan keragaman varian penafsiran. Keragaman itu seperti tafsir AlQur'an yang memiliki wawasan budaya lokal dan lokalitas yang memiliki wawasan Al-Qur'an. ${ }^{38}$ Di Minangkabau korelasi Al-Qur'an dengan budaya lokal tersebut terpatri pada adagium Adat Basandi Syarak, Syarak Basandi Kitabullah, Syarak Mangato, Adat Mamakai. Dengan demikian, mengakomodir lokalitas dalam penafsiran menjadi sebuah keniscayaan.

Tempat penulisan kitab tafsir bagi penulisnya, memungkinkan akan terakomodirnya lokalitas setempat dalam penulisannya, dan tentunya memiliki latar belakang yang mesti diungkapkan karena tanpa latar belakang tersebut mustahil sebuah karya tafsir akan memunculkan aspek lokalitas dalam tafsirnya. Di samping latar belakang, pemilihan metode dan sajian penafsirannya juga mempengaruhinya, karena tujuan dari tafsir yang hendak dihasilkan adalah untuk menyampaikan pesan firman Allah SWT kepada masyarakat lokal dan atau negara tempat penafsir itu menetap.

Praktik atau serapan lokalitas tafsir Al-Qur'an Minangkabau akan penulis lihat pada tiga karya tafsir yang menjadi objek penelitian dalam penelitian ini yakni

\footnotetext{
${ }^{36}$ Izzul Fahmi, Lokalitas Tafsir di Indonesia: Studi Corak Kebudayaan dalam kitab Tafsir al-Ibrīz, Tesis pada Pasca Sarjana Universitas Islam Negeri Sunan Ampel Surabaya, tahun 2017.

${ }^{37}$ Jajang A Rohmana, Sejarah Tafsir Al-Qur'an di Tatar Sunda, Bandung, Mujahid Press, cetakan ke2, 2017. Ha.86.

${ }^{38}$ Aksin Wijaya, Relasi Al-Qur'an dan Budaya Lokal (Sebuah Tatapan Epistemologis), t.tp, t.th. $1-16$.
} 
kitab tafsir al-Burbân karya Haji Abdul Karim Amrullah, Risalâh al-Qaul al-Bayân karya Syeikh Sulaiman Arrasuli, dan al-Da'wah wa al-Irsyâd ilâ Sabîl al-Rasyâd karya Abdul Lathif Syakur.

Serapan unsur lokalitas yang penulis maksud dalam temuan penelitian ini adalah segala hal yang berhubungan dengan masyarakat lokal Minangkabau yang dimulai dari keinginan masyarakat supaya ulama Minangkabau menulis kitab tafsir sebagai panduan untuk memahami kitabullah, keterserapan bahasa lokal Minangkabau, serapan sampel lokal, serapan kebiasaan (budaya) lokal, dan serapan adagium lokal Minangkabau.

\section{Penulisan Tafsir dalam Rangka Memenuhi Permintaan Masyarakat}

Keterserapan lokalitas dalam sebuah kitab tafsir mesti diperhatikan adalah latar belakang penulisan tafsir tersebut. Tiga tafsir Al-Qur'an Minangkabau (tafsir al-Burbân karya Haji Abdul Karim Amrullah, Risalâh al-Qaul al-Bayân karya Syeikh Sulaiman Arrasuli, dan al-Da'wah wa al-Irsyâd ilâ Sabîl al-Rasyâd karya Abdul Lathif Syakur) yang menjadi objek penelitian ini, memiliki latar belakang penulisan yang menggambarkan akan hajat penduduk lokal Minangkabau.

\section{a. Latar belakang penulisan al-Burhân}

Alasan penulisan kitab tafsir al-Burbân, sebagaimana disebutkan oleh Haji Abdul Karim Amrullah dalam mukadimah tafsirnya ${ }^{39}$ bahwa penulisan tafsir alBurbân dilatar belakangi oleh permintaan murid-muridnya yang selalu menghadiri kajian tafsirnya di Surau Jembatan Basi Padang Panjang, ${ }^{40}$ dan di samping itu ia menyebutkan dalam rangka memberdayakan akal untuk memahami ayat-ayat Allah, karena Allah SWT menyuruh hamba-Nya untuk mempergunakan akal dan pikiran agar dapat digunakan dengan sebaik-baiknya. Argumentasi dalam rangka memberdayakan akal tersebut oleh Haji Abdul Karim Amrullah dikuatkannya dengan firman Allah dalam surat Shat ayat 29.

Kehadiran kitab al-Burbân sebagai tafsir atas ayat-ayat Al-Qur'an terkhusus tafsir atas Qs. Adh-Dhuha sampai Qs.al-Nâs, hadir di tengah masyarakat Minangkabau yang sedang dihadapkan pada dinamika, polemik, dan dialektika antara Kaum Tua dan Kaum Muda, yang mana pengarang al-Burbân adalah tokoh utama Kaum Muda dalam perseteruan paham, ideologi dan gagasan. Di samping itu kehadiran kitab al-Burbân juga di tengah polemik Haji Abdul Karim Amrullah

${ }^{39}$ Haji Abdul Karim Amrullah, al-Burbân, 3-16.

${ }^{40}$ Surau Jembatan Basi di Padang Panjang adalah tempat Haji Abdul Karim Amrullah mengisi kajian-kajian keislaman termasuk kajian tafsir Al-Qur'an. Kajian tersebut mulai banyak diminati oleh Masyarakat Padang Panjang dan bahkan dari luar Padang Panjang, dan pengajian di Surau Jembatan Basi itu juga merupakan cikal bakal lahirnya Thawalib Padang Panjang. 
dengan kelompok adat, ia membantah adat dan kebudayaan Minangkabau sepeti masalah harta waris. ${ }^{41}$

\section{b. Latar belakang penulisan tafsir Risâlah al-Qaul al-Bayân fî Tafsît al- Qur'ân}

Kitab Risâlah Al-Qaul Al-Bayân fî Tafsîr Al-Qur'ân, sebagaimana kitab alBurbân juga memiliki latar belakang penulisan yang mirip yaitu berdasarkan permintaan. Syeikh Sulaiman Arrasuli diminta masyarakat, dan saudaranya untuk menulis tafsir Al-Qur'an dengan bahasa Arab-Melayu. Permintaan tersebut membuatnya ragu (taradud) antara menulis kitab tafsir atau tidak. Keraguan Syeikh Sulaiman Arrasuli digambarkannya "tidak ada faedabnya menulis kitab tafsir dengan menggunakan bahasa Arab-Melayu", di samping itu ia juga beranggapan bahwa mengetahui hukum-hukum yang termaktub dalam Al-Qur'an tidak mungkin kalau tidak menguasai ilmu Arabiyah yang dua belas, ilmu ushul, ilmu qira'at, ilmu hadis, dan lain-lain dari pada perkakas ijtihad. ${ }^{42}$ Kendatipun ada keraguan dalam menulis tafsir, pada akhirnya Syeikh Sulaiman Arrasuli memperkenankan permintaan untuk menulis kitab tafsir dengan menggunakan bahasa Arab-Melayu, dengan alasan sekira-kira penghasil khusuk dalam Shalat ada juga faedah dan manfaatnya. 43

Dari alasan penulisan tafsir Risâlah Al-Qaul Al-Bayân fì Tafsì Al-Qur'ân tersebut di atas, memperlihatkan bahwa Syeikh Sulaiman Arrasuli memperkenankan permintaan masyarakat lokal Minangkabau, hal tersebut adalah bentuk dari aspek lokal.

\section{c. Latar belakang penulisan al-Da'wah wa al-Irsyâd Ilâ Sabîl al-Rasyâd}

Berbeda dengan alasan penulisan kitab tafsir al-Burbân dan Risâlah al-Qaul al-Bayân fì Tafsìr Al-Qur'ân, tafsir al-Da'wah wa al-Irsyâd Ilâ Sabîl al-Rasyâd dilatar belakangi oleh keinginan penulis untuk mengumpulkan ayat-ayat Allah yang menunjukkan beberapa keadaan manusia yang terhimpun pada ayat-ayat yang di awali oleh wa min al-Nâs. ${ }^{44} \mathrm{Di}$ samping itu penulisan tafsir al-Da'wah wa al-Irsyâd Ilâ Sabîl al-Rasyâd oleh Abdul Lathif Syakur adalah salah satu bentuk metode dakwahnya kepada masyarakat Minangkabau, khususnya masyarakat Balai Gurah.

\footnotetext{
${ }^{41}$ Informasi terkait harta waris ini lihat, Haji Abdul Karim Amrullah, al-Fara'id (tuntunan pembagian harta waris), 1932.

${ }^{42}$ Syeikh Sulaiman Arrasuli, Risâlah Al-Qaul Al-Bayân Fî̀ Tafsîr Al-Qur'ân, Bukittinggi: Mathba'ah al-Islâmiyah Fort De Kock, 1927, 1-2.

${ }^{43}$ Syeikh Sulaiman Arrasuli, Risâlah Al-Qaul Al-Bayân Fî̀ Tafsî̀ Al-Qur'ân, Bukittinggi: Mathba'ah al-Islâmiyah Fort De Kock, 1927, 1-2.

${ }^{44}$ Abdul Lathif Syakur, Al-Da'wah Wa Al-Irsyâd Ilâ Sabîl Al-Rasyâd, Bukittinggi: tsamarah al-Ikhwan, 1370 H/1951M, 2.
} 
Ia mencoba mendekatkan masyarakat dengan kitabullah secara tematik, dalam hal ini terkait dengan ayat-ayat yang berhubungan dengan manusia (wa min al-Nâs).

Alasan penulisan tersebut, menunjukkan akan kepedulian Abdul Lathif Syakur terhadap masyarakat Minangkabau, menunjukkan bahwa kitab tafsir yang ditulisnya ini merupakan kitab yang kental dengan unsur lokalnya, yang pada penjelasan berikutnya akan penulis jelaskan unsur lokalitas lainnya yang terdapat dalam tafsir Al-Da'wah Wa Al-Irsyâdd Ilâ Sabîl Al-Rasyâd.

\section{Keterserapan Bahasa Lokal}

Sebagai bentuk serapan lokalitas dalam tafsir Al-Qur'an Minangkabau yang penulis temukan dalam tiga kitab tafsir (al-Burbân karya Haji Abdul Karim Amrullah, Risalâh al-Qaul al-Bayân karya Syeikh Sulaiman Arrasuli, dan al-Da'wah wa al-Irsyâd ilâ Sabîl al-Rasyâd karya Abdul Lathif Syakur), yang menjadi objek penelitian ini adalah serapan bahasa lokal Minangkabau dan atau menggunakan bahasa lokal untuk menerjemahkan dan menjelaskan penafsiran ayat-ayat AlQur'an. Menggunakan bahasa lokal dalam menerjemahkan Al-Qur'an dan menafsirkannya disebut juga dengan vernakularisasi dalam istilah A.H. Jhons. ${ }^{45}$

\section{a. Bahasa Minang dalam tafsir al-Burhân}

Haji Abdul Karim Amrullah dalam menulis tafsirnya dan masyarakat Minangkabau yang menjadi pembacanya, maka sulit untuk tidak terpengaruh oleh bahasa lokal Minangkabau, artinya dalam penulisan al-Burhân, Haji Abdul Karim Amrullah juga menggunakan bahasa lokal, paling tidak adalah alih bahasa atau terjemahan Al-Qur'an dan atau penjelasan tafsirinya. Hal tersebut terbukti dengan temuan penulis, bahwa dalam tafsir al-Burbân terdapat beberapa kosa kata Minangkabau yang menunjukkan akan adanya vernakularisasi dalam kitab tafsir al-Burhân yaitu,

1) Pakak dan Rabun

Ditemukan dalam beberapa penjelasan Haji Abdul Karim Amrullah yang menggunakan bahasa daerah Minangkabau seperti pakak dan rabun, kedua kata tersebut digunakannya untuk menerangkan makna tsumma radadnâhu asfala sâfilîn.

${ }^{45}$ A.H. Jhons menyebutkan bahwa vernakularisasi (pembumian melalui bahasa lokal) AlQur'an yang melekat pada bahasa tafsir yang otoritatif. Lihat A.H. Jhons, "Tafsir Al-Qur'an di Dunia Melayu: Sebuah Penelitian Awal” dalam Jurnal Studi Al-Qur'an, Vol. 1, No. 3, 2006, 459486. Selain itu Farid F Saenong dalam wawancaranya dengan A.H.Jhons, menyebutkan bahwa dalam perspektif A.H.Jhons penafsiran masyarakat terhadap Al-Qur'an baik dalam bentuk penafsiran fiqh maupun hadis, kemudian menjadikannya suatu yang lazim dalam bahasa Indonesia atau Melayu. Lihat Interview dengan Profesor Anthony H. Jhons, "Vernacularization of The Qur'an: Tantangan dan Prospek Tafsir Al-Qur'an di Indonesia”, dalam Jurnal Studi Al-Qur'an, Vol. 1, No. 3, 2006, 575-590. 
Dalam Kamus Umum Bahasa Minangkabau kata pakak artinya adalah tuli, dan kata rabun artinya penglihatan kabur. ${ }^{46}$

Kedua kosa kata Minang tersebut digunakan oleh Haji Abdul Karim Amrullah ketika menjelaskan penafsiran Qs. At-Tin ayat 5. Ia menerangkan bahwa yang dikehendaki dengan sehina-hina orang yang hina (asfala sâfilîn)adalah hina pada dunia "bungkuk pada kemudian lurus, putib rambut sesudahnya bitam, kerinyut kulit sesudahnya tegang, lemah sesudah kuat, tanggal gigi, pakak, rabun, kurang akal, dan rusak malu dan sopan". ${ }^{47}$

2) Manungkut, pijak-pijak, dan managah

Ditemukan juga dalam al-Burban kata manungkut yang memiliki arti menundukkan, kata pijak-pijak bermakna menginjak-injak dengan kaki, dan kata managah artinya adalah melarang. ${ }^{48}$ Kata-kata tersebut digunakan oleh Haji Abdul Karim Amrullah untuk menjelaskan penafsiran Qs. Al-'Alaq ayat 9 dan ayat 10. ${ }^{49}$ Ayat tersebut menerangkan perilaku Abu Jahl terhadap Rasulullah yang sedang melaksanakan Shalat di dekat Ka'bah. Abu Jahl menginjak-injak kuduk Rasulullah ketika sedang sujud/menunduk. Dalam rangka menggambarkan perilaku Abu Jahl tersebut terhadap Nabi SAW, Haji Abdul Karim Amrullah menggunakan bahasa Minang "jika melibat aku akan Mubammad memperbuat begitu (sembahyang) aku pijakpijak (injak-injak) kuduknya dan aku pupurkan mukanya ketanab"50

\section{b. Bahasa Minang dalam tafsir Risâlah al-Qaul al-Bayân}

Tafsir Al-Qur'an di Minangkabau ditemukan dalam dua ragam tulisan, pertama dengan tulisan Arab-Melayu dan yang kedua dengan tulisan roman atau latin. Tafsir Risâlah al-Qaul al-Bayân sebagai salah satu tafsir Al-Qur'an di Minangkabau yang ditulis dengan menggunakan Arab-Melayu ${ }^{51}$ sama dengan

${ }^{46}$ Abdul Kadir Usman, Dt. Yang Dipatuan, Kamus Umum Bahasa Minangkabau Indonesia, Padang: Angrek Media, 2002, 426 \&458.

${ }^{47}$ Haji Abdul Karim Amrullah, al-Burbân..., 70.

${ }^{48}$ Abdul Kadir Usman, Dt. Yang Dipatuan, Kamus Umum Bahasa Minangkabau Indonesia, Padang: Angrek Media, 2002, 446 \&516.

${ }^{49}$ Haji Abdul Karim Amrullah, al-Burbân..., 96.

${ }^{50}$ Haji Abdul Karim Amrullah, al-Burbân, 96.

${ }^{51}$ Sudah jamak diketahui bahwa pada awal-awal abad ke-20 aksara yang berkembang adalah aksara Arab-Melayu, semua karya tulis yang bermunculan pada masa itu ditulis dengan berbahasa Arab dan dengan aksara Arab-Melayu. Sama halnya dengan Minangkabau, di Jawa tulisan atau aksa yang berkembang disebut dengan aksara Arab-Pegon. Tulisan Arab-Pegon digunakan dalam penulisan kitab tafsir oleh ulama-ulama Jawa seperti yang digunakan oleh K.H Muḥammad Sâliḥ bin 'Umar al-Samaranî (1820-1903) yang terkenal dengan sebutan Kiai Saleh Darat, ia menulis tafsir Faị ar-Raḥmân fí Tarjamah Kalâm Mâlike ad-Dayyân. Kemudian ulama jawa yang menggunakan akasara Arab Pegon adalah K.H. Misbah Zainul Mustafa Bangilan (1916-1994) 
tafsir al-Burbân karya Haji Abdul Karim Amrullah juga sarat dengan serapan bahasa Minangkabau, hal yang tidak bisa dihindarkan, karena bahasa lokal Minangkabau begitu melekat pada sosok Syeikh Sulaiman Arrasuli, sehingga sangat wajar akan ditemui bahasa daerah Minangkabau dalam tafsirnya sebagai bentuk dari vernakularisasi.

1) Nan. Hal. 22, 23, 62, dan 111.

Nan dalam bahasa Minangkabau memiliki arti "yang." Penggunaan kata ini sering ditemui dalam adagium atau pepatah Minang seperti "Nan Tinggi Tanpake Jauah, Nan Gadang Jolong Basuo"52 artinya adalah yang tinggi tampak/kelihatan jauh, yang besar baru bersua/bertemu. Sedangkan kata "yang" dalam bahasa Arab menunjukkan makna sifat.

Bahasa Minang "Nan" ini ditemukan dalam tafsir Risâlah al-Qaul al-Bayân terdapat pada halaman 22 ketika Syeikh Sulaiman Arrasuli menjelaskan penafsiran Qs. An-Nazi'at ayat 27. Selai, itu juga ditemukan penggunaan kata "nan" pada halaman 23 masih menjelaskan tafsir Qs. An-Nazi'at ayat 47, ditemukan juga pada halaman 62 ketika menjelaskan penafsiran Qs.al-A'la ayat 6, dan juga penulis temukan pada halaman 111 ketika Syeikh Sulaiman Arrasuli menafsirkan Qs. AlHumazah ayat 5.

2) Masiak, hal. 61

yang menulis al-Iklîl fi Ma'ânî at-Tañîl dan K.H. Bisri Mustafa Rembang (1915-1977) yang menulis al-Ibrîz, li Ma'rifati Tafsîr al-Qur'ân al-'Azî̌. Islah Gusmian, Tafsir Al-Qur'an Bahasa Jawa, Peneguhan Identitas, Ideologi, dan Politik, Jurnal Șuhuf, Vol. 9, No. 1, Juni 2016, hlm. 141-168. ISSN 1979-6544; eISSN 2356-1610; http://jurnalsuhuf.kemenag.go.id. Penggunaan bahasa ArabMelayu sejatinya juga bentuk dari Serapan lokalitas itu sendiri. Literatur yang berhubungan dengan keagamaan di Minangkabau dituliskan dengan menggunakan tulisan Arab-Melayu, bahkan A.H. Jhons menyatakan bahwa bahasa Melayu telah digunakan di Nusantara sejak Abad XV. Lebih lanjut A.H. Jhons mengatakan bahwa bahasa Melayu memiliki peran khusus dalam dakwah Islam. Lihat Anthony H. Johns, Tafsir al Qur an di Dunia Indonesia Melayu, Sebuah Penelitian Awal Jurnal Studi Al-Qur'an Vo. 1, No. 3, 2006. ISSN 1907-1302 http://tempatbagibagi.blogspot.com/2011/07/unduh-jurnal-studi-al-quran-vol-1-no-3.html akses 28/11/2018 dan https://iiq.ac.id/index.php?a=artikel\&d=2\&id=113akses 28/11/2018. Tulisan Arab-Melayu merupakan bentuk nyata dari pengaruh Islam terhadap dunia Melayu terutama masyarakat Minangkabau. Bentuk tulisan tersebut masih bertahan sampai awal abad ke 20, yang dibuktikan dengan karya-karya tulis ulama Minangkabau termasuk dalam penulisan kitab tafsir. Kendatipun tulisan latin sudah mulai dikenalkan di Nusantara terutama bagi anak-anak pribumi yang sekolah di sekolah Belanda, namun tulisan tersebut belum begitu popular di kalangan orang Minangkabau. Pilihan bahasa dalam sebuah karya akan menunjukkan maksud dan tujuan serta sasaran dari tulisan yang disajikan termasuk tulisan tafsir. Kehadiran karya tafsir di tengahtengah masyarakat akan memberikan pedoman dan petunjuk serta merupakan sebuah solusi dari problem yang sedang terjadi di masyarakat tempat tafsir itu ditulis.

${ }^{52} \mathrm{Abdul}$ Kadir Usman, Dt. Yang Dipatuan, Kamus Umum Babasa Minangkabau Indonesia, Padang: Angrek Media, 2002, 406. 
Masiak artinya adalah kering. ${ }^{53}$ Kata masiak ini sering digunakan untuk mengatakan sesuatu yang sudah matang atau garing seperti karupuak masiak (kerupuk kering/garing). Kata masiak ini digunakan oleh Syeikh Sulaiman Arrasuli untuk menjelaskan perubahan yang terjadi pada rumput, hal ini ditemukan ketika ia menafsirkan Qs. Al-A'lâ ayat 4-5. Dan orang yang mengeluarkan akan Tuban akan rumput, menumbubkan Tuhan akan dia, kemudian menjadikan Tuban akan rumput itu kemudian muda akan masiak lagi bancur.

Penggunaan kata masiak oleh Syeikh Sulaiman Arrasuli untuk menerjemahkan kata غُنَاء adalah untuk mendekatkan paham dan makna ayat tersebut kepada masyarakat yang sehari-hari di Minangkabau menggunakan kata masiak untuk menerangkan rumput kering dan mudah hancur.

Beberapa kosakata Minangkabau yang telah dijelaskan di atas cukup untuk menjelaskan bahwa bahasa Minangkabau telah meresapi tafsir Risâlah al-Qaul alBayân karya Syeikh Sulaiman Arrasuli. Serapan bahasa Minang tersebut adalah salah satu bukti bahwa kitab tafsir ini sarat dengan unsur-unsur lokal yang meresapinya. Inilah yang disebut dengan vernakularisasi dalam istilah A.H. Jhons. ${ }^{54}$

c. Bahasa Minang dalam tafsir Al-Da'wah Wa Al-Irsyâd Ilâ Sabîl Al-Rasyâd

Sebagaimana hal karya Haji Abdul Karim Amrullah dan karya Syeikh Sulaiman Arrasuli terdapat di dalamnya bahasa lokal Minangkabau begitu juga dengan Abdul Lathif Syakur, ditemukan juga dalam karyanya $A l-D a^{\prime} w a h$ Wa $A l-$ Irsyâd Ilâ Sabîl Al-Rasyâd. serapan bahasa Minang dalam tafsirnya, penulis temukan diantaranya; penggunaan kata tangguli yang tedapat pada halaman 10. Kata “tangguli" merupakan bahasa Minang yang memiliki arti manisan. ${ }^{55}$ Kata ini sering digunakan dalam pepatah orang Minang seperti barundiang pandai samo pandai, bake santan jo tangguli. Artinya berunding sama-sama pandai bagai bercampurnya santan dan manisan.

Kata tangguli digunakan oleh Abdul Lathif Syakur untuk menjelaskan sifat orang munafik yang terdapat dalam Qs. Al-Baqarah ayat 204-206. Diujung penjelasannya Abdul Lathif Syakur memperingatkan orang-orang muslim jangan

\footnotetext{
${ }^{53}$ Abdul Kadir Usman, Dt. Yang Dipatuan, Kamus Umum Bahasa Minangkabau Indonesia, Padang: Angrek Media, 2002, 395.

${ }^{54}$ Anthony H. Johns, "Quranic Exegesis in the Malay World", dalam Andrew Rippin (ed.), Approaches to the History of the Interpretation of the Qur'an (OxFor: Clarendon Press, 1988), 257-87; Anthony H. Johns, "Vernacularization of the Qur"ean: Tantangan dan Prospek Tafsir Al-Qur"ean di Indonesia”, dalam Jurnal Studi Qur’an, Vol. 1, No. 3, 2006, 579.

55 Abdul Kadir Usman, Dt. Yang Dipatuan, Kamus Umum Bahasa Minangkabau ...., 529.
} 
sampai seperti kebanyakan bermulut tangguli berhati duri. Artinya orang munafik itu hanya bermanis mulut saja.

Bahasa Minang lainnya yang diserap oleh Abdul Lathif Syakur adalah "konco". Konco artinya adalah teman dekat. Penggunaan kata ini ketika menerangkan 'Uqbah bin Mu'it menginjak-injak kuduk dan leher Rasulullah ketika beliau sembahyang di dekat Ka'bah bersama-sama dengan konconya. ${ }^{56}$

Bahasa Minang yang sangat popular sebutannya juga digunakan oleh Abdul Lathif Syakur dalam tafsirnya ini, yaitu sebutan Niniak mamak. ${ }^{57}$ Sebutan niniak mamak di Minangkabau digunakan untuk panggilan kepada saudara laki-laki dipihak ibu dan setiap orang laki-laki yang sepersukuan. Di samping itu niniak mamak juga terkhusus kepada pemangku adat di Minangkabau yaitu sebutan kepada pimpinan adat seperti datuk (penghulu).

\section{Menggunakan Sampel Lokal dalam Penafsiran}

Serapan lokalitas dalam tafsir Al-Qur'an Minangkabau juga terlihat dalam penggunaan sampel lokal dalam penafsiran. Kendatipun penyebutan sampel lokal ini tidak ditemukan dalam ketiga kitab tafsir yang menjadi objek penelitian penulis, namun demikian penulis menemukan penyebutan sampel lokal ini seperti dalam tafsir al-Burhân.

Haji Abdul Karim Amrullah sangat jelas menggunakan dan menyebutkan sampel lokal dalam penafsirannya. Hal ini terlihat ketika Haji Abdul Karim Amrullah menyebutkan pekerjaan yang digeluti oleh masyarakat Minangkabau, yaitu bersawah, berladang, bertukang, dan sebagainya. ${ }^{58}$ Penyebutan contoh pekerjaan yang digeluti oleh masyarakat lokal Minangkabau adalah dalam rangka menjelaskan tentang amalan yang didasari niat yang ikhlas, ${ }^{59}$ bahwa apa pun pekerjaan seseorang jika dia niatkan untuk beribadah ikhlas karena Allah maka pekerjaan tersebut akan dinilai ibadah disisi Allah SWT, karena memang esensi manusia diciptakan Allah adalah untuk beribadah kepada-Nya Qs. Az-Zariyât 56.

\section{Serapan Budaya Lokal}

Budaya Minangkabau yang penulis maksud adalah kebiasaan yang dilakukan oleh orang Minangkabau dalam kehidupan sehari-hari. Di antara

56 Abdul Lathif Syakur, al-Da’wah.... Hal, 14.

${ }^{57}$ Abdul Lathif Syakur, al-Da'wah..., 23.

${ }^{58} \mathrm{Haji}$ Abdul Karim Amrullah, al-Burhân, 123.

${ }^{59}$ Ikhlas menurut Haji Abdul Karim Amrullah terbagi pada empat, yaitu 1) menetapkan hati bagi Allah semata-mata pada beribadah, 2) menyengaja dengan ibadah akan ridha Allah, 3) mendatangkan perbuatan ibadah karena perintah Allah semata-mata tidak karena ria, dan 4) niat yang bersih suci dari pada unsur-unsur ria dan yang seumpamanya. Haji Abdul Karim Amrullah, al-Burhân, 122-123. 
budaya tersebut adalah mamak atau niniak mamak ${ }^{60}$ membimbing anak kemenekan, seperti yang sudah menjadi petatah-petitih orang Minangkabau kaluak paku, asam balimbiang, tampuruang lenggang lenggokekan, anak dipangku kemenakan dibimbiang urang kampuang dipatenggangkan.

Kebiasaan masyarakat lokal Minangkabau menjadi salah satu bentuk serapan lokalitas dalam tafsir al-Qur'an Minangkabau, dari tiga kitab tafsir yang menjadi objek penelitian, penulis menemukan dalam dua kitab tafsir yang menyerap kebiasaan masyarakat Minangkabau, yaitu terutama kitab tafsir alBurbân karya Haji Abdul Karim Amrullah dan Risâlah al-Qaul al-Bayân karya Syeikh Sulaiman Arrasuli.

\section{a. Baik-baik memakaikan adat}

Haji Abdul Karim Amrullah dalam tafsir al-Burbân menjelaskan penafsiran Qs. Al-'Ashr ayat 3. Dalam penjelasannya tentang 'Amil as-Shalibât, ia menyebutkan bahwa salah satu amalan Shaleh itu adalah baik-baik memakaikan adat, hal ini terkait antara anak dengan ibu bapak, ba dunsanak, ${ }^{61}$ berkemenakan, ${ }^{62}$ bersuami istri, berkaum dan berfamili, ba Koto ba Nagari, ${ }^{63}$ berkorong berkampung dan lain-lain. ${ }^{64}$

Maksud dari kata baik-baik memakaikan adat adalah sesuai patut dengan mungkin bergaul dengan orang-orang yang telah di sebutkan di atas, hal tersebut

${ }^{60} \mathrm{Mamak}$ memiliki dua pengertian yaitu pengertian genealogis dan pengertian sosiologis. Mamak dalam pengertian genealogis adalah saudara laki-laki dari ibu yang berfungsi sebagai pemimpin kaumnya. Sedangkan mamak dalam pengertian sosiologis adalah semua laki-laki yang lebih tua dan yang dituakan dalam suatu kaum (suku). Febri Yulika, Epistemologi Minangkabau, ... 20. Mamak di Minangkabau tidak sama pengertiannya dengan sebutan Om atau paman dalam pengertian Bahasa Indonesia, seperti itulah dalam perspektif Saydam. Gouzali Saydam, Kamus Lengkap Babasa Minang (Minang-Indonesia), Padang: PPIM Sumatera Barat, 2004, 241.

${ }^{61}$ Ba dunsanak artinya adalah bersaudara, baik saudara dari pihak ibu maupun saudara dari pihak ibu.

${ }^{62}$ Berkemenakan berasal dari kata kemenakan. Kemenakan artinya adalah anak dari pihak saudara perempuan di Minangkabau yang memiliki suku yang sama. Sedangkan makan berkemenakan adalah pergaulan mamak dengan kemenakannya dan atau bagaimana sikap mamak kepada kemenakannya tersebut.

${ }^{63}$ Nagari adalah sebutan sistem pemerintahan yang berdasarkan hukum adat. Nuraini Budi Astuti dkk, menyebutkan bahwa secara tradisional masyarakat Minang hidup berkelompok dalam suatu ikatan genealogis dan teritorial yang otonom dengan pemerintahan yang kolektif berdasarkan hukum adat dalam sebuah sistem pemerintahan yang disebut nagari. Nuraini Budi Astuti, Laila M. Kolopaking, dan Nurmala K Panjaitan, Dilema dalam Transformasi Desa Ke Nagari: Studi Kasus di Kanagarian IV Koto Palembayan Provinsi Sumatera Barat, Sodality Jurnal Transdisiplin Sosiologi, Komunikasi, dan Ekologi Manusia. Agustus 2009, hlm153-172. Vol.3, no 22009.

${ }^{64}$ Haji Abdul Karim Amrullah, al-Burbân, 189. 
juga mesti sesuai dengan ketetapan dan peraturan Allah dan Rasul-Nya. Di samping itu adalah bentuk budaya lokal masyarakat Minangkabau yang selalu menjunjung tinggi adat-istiadatnya.

Setalah menjelaskan "baik-baik memakaikan adat" Haji Abdul Karim Amrullah merekomendasikan kepada pembaca dalam tafsirnya ini untuk pengetahuan lebih lanjut dan penjelasan panjang lebar bacalah kitab Sandi Aman Tiang Selamat.

\section{b. Perlakuan orang Minangkabau terhadap anak yatim}

Syeikh Sulaiman Arrasuli dalam tafsirnya Risâlab al-Qaul al-Bayân, menjelaskan bahwa orang Minang harus mengayomi anak kemenakannya, termasuk kemenakan yang sudah yatim, hal ini dijelaskannya, ketika menafsirkan Qs. Al-Mâ'ûn/107:2;

Syeikh Sulaiman Arrasuli dalam menjelaskan penafsiran ayat di atas sesuai dengan konteks Minangkabau dalam hal ini adalah memperlakukan anak yatim. Anak yatim menurut Syeikh Sulaiman Arrasuli adalah seorang kanak-kanak yang kematian bapak sekalipun ibunya masih ada. ${ }^{65}$ Anak yatim yang dimaksudnya adalah bukan yatim binatang. Yatim binatang adalah yang tidak ada ibu bapaknya.

Setelah mendefinisikan anak yatim, Syeikh Sulaiman Arrasuli menjelaskan ayat tersebut dengan menyatakan bahwa makna menolak (menghardik) anak yatim, pertama, mengambil haknya, aniaya kepadanya dengan mengambil baknya serta harta peninggalan bapaknya dan lain-lain sepeti yang berlaku di Minangkabau. Penjelasan tersebut bermakna menganiaya anak yatim dengan mengambil harta dan haknya yang ditinggalkan oleh bapaknya. Syeikh Sulaiman terlihat emosional dalam menjelaskan ayat ini karena telah terjadi di negeri Minangkabau orang-orang yang semena-mena terhadap anak yatim, mamak tidak lagi menjalankan fungsinya sebagai mamak yang mengayomi kemenakannya. Kedua, menyuruh bekerja; menyuruh anak itu kepada sekalian pekerjaan yang bukan kerjanya atau meninggalkan menolongnya dengan menghela manfaat baginya dan menolak mudarat darinya. Termasuk juga menolak yatim atau menghardik anak yatim adalah menyuruhnya untuk melakukan pekerjaan yang bukan kerjanya. Ketiga, meninggalkan menolongnya. termasuk juga menolak yatim adalah meninggalkan menolongnya dengan memberi manfaat baginya dan menolak atau menghilangkan mudarat darinya. Lebih lanjut Syeikh Sulaiman Arrasuli menjelaskan hal yang demikian dengan mengatakan tuan-tuan libatlah apa yang bisa diperbuatkan orang kepada anak yatim di Minangkabau kita ini. ${ }^{66}$ Artinya tuan-tuan perhatikanlah bagaimana orang Minangkabau memberlakukan anak yatim.

\footnotetext{
${ }^{65}$ Syeikh Sulaiman Arrasuli, Risalah ..., 115.

${ }^{66}$ Syeikh Sulaiman Arrasuli, Risalah ..., 115.
} 
Orang Minangkabau yang terkenal dengan adagium "Kaluak Paku Asam Balimbiang, Tampuruang Lenggang Lenggokkan, Anak dipangku Kemenakan di bimbiang, urang Kampuang dipatenggangkan” artinya adalah anak di pangkuan, kemenakan di bimbing, orang kampung diayomi. Sudah barang tentu menghardik anak yatim dan menelantarkannya bukanlah sifat dan budaya orang Minangkabau. Sifat orang Minangkabau adalah mengayomi dan membimbing anak-anak yatim. Membimbing dan mengayomi tersebut merupakan tanggung jawab mamaknya di samping tanggung jawab sebagai muslim secara umum.

Syeikh Sulaiman Arrasuli memberikan gambaran bagaimana memperlakukan anak yatim di Minangkabau dalam karya beliau yang berjudul Pedoman Hidup Alam Minangkabau. ${ }^{67}$ Syeikh Sulaiman Arrasuli menjelaskan dengan kisah Siti Budiman yang telah ditinggal mati oleh suaminya (Muhammad Shadiq bergelar Pakiah Alam), meninggalkan dua orang anak yang bernama Muhammad Arif dan Siti Arifah. Dalam kisah tersebut Siti Budiman dan anak-anaknya hidup pas-pasan. Di samping itu Siti Budiman memiliki saudara laki-laki yang juga seorang datuak yang bernama Datuak Rajo Adil. Datuak Rajo Adil adalah mamak dari anak-anak Siti Budiman. Secara adat di Minangkabau mamak bertanggungjawab atas kemenakannya baik keberlangsungan hidup maupun dalam aspek pendidikan dan lainnya.

Siti Budiman yang memahami akan hal itu, meminta pendapat kepada Datuak Rajo Adil, bagaimana dengan masa depan anak-anaknya? Muhammad Arif sudah berumur 7 tahun dan sudah selayaknya mendapatkan pendidikan atau dimasukkan ke Sekolah Dasar (SD), mendengar hal itu Datuak Rajo Adil mendukung keinginan yang disampaikan oleh Siti Budiman. Datuak Rajo Adil selaku mamak oleh Muhammad Arif mengantarkannya pergi mendaftar untuk masuk SD. Pekerjaan yang dilakukan oleh Datuak Rajo Adil adalah bentuk tanggung jawabnya kepada kemenakannya yang sudah tidak punya ayah atau yatim. $^{68}$

Begitulah gambaran bagaimana orang Minangkabau memberlakukan anak yatim. Sudah jamak diketahui bahwa dalam tatanan sosial di Minangkabau seseorang memiliki berbagai peran, yaitu sebagai bapak/ibu, mamak/kemenakan, dan sebagainya. Mamak berfungsi sebagai pengayom bagi para kemenakannya.

Perhatian Syeikh Sulaiman Arrsuli terhadap anak Yatim di Minangkabau menjadi bukti kuat bahwa tafsirnya ini sarat dengan lokalitas. Dan memang tafsir ini ditujukannya untuk masyarakat Minangkabau.

\footnotetext{
${ }^{67}$ Syeikh Sulaiman Arrasuli, pedoman Hidup di alam Minangkabau menurut garisan adat dan syarak, Bukittinggi: Tsamarah al-Ikwan, 1939., 10-38.

${ }^{68}$ Syeikh Sulaiman Arrasuli, pedoman Hidup, ... 10-38.
} 


\section{Menggunakan Adagium Lokal}

Dalam tradisi Minangkabau menggunakan adagium atau petatah-petitih merupakan hal yang lazim dalam komunikasi masyarakat Minangkabau, baik komunikasi lisan ataupun tulisan. Penggunaan adagium di Minangkabau adalah bentuk distingsi masyarakat yang sarat akan makna filosofis. Kelaziman masyarakat Minangkabau menggunakan adagium tersebut tidak dapat dihindarkan dalam sebuah karya, termasuk karya tafsir Al-Qur'an.

Dalam tafsir al-Burbân karya Haji Abdul Karim Amrullah, Risalâb al-Qaul al-Bayân karya Syeikh Sulaiman Arrasuli, dan al-Da'wah wa al-Irsyâd ilâ Sabîl alRasyâd karya Abdul Lathif Syakur, penulis menemukan berbagai bentuk adagium yang digunakannya dalam menjelaskan maksud dari kitabullah.

\section{a. Dalam tafsir al-Burhân}

Dalam komunikasi orang Minangkabau, baik komunikasi lisan atau pun tulisan sarat akan adagium/petatah-petitih. Sebagai orang Minangkabau Haji Abdul Karim Amrullah juga menggunakan hal yang sama dalam tulisannya. Hal tersebut menunjukkan serapan lokal begitu terlihat dalam tafsirnya. Penulis menemukan ada dua adagium yang terdapat dalam tafsir al-Burbân, yaitu;

1) Hawa yang pantang karandaban, napasu yang pantang kakurangan

Penjelasan Haji Abdul Karim Amrullah terhadap Qs. Al-Bayyinah ayat 23; Ayat tersebut menjelaskan bahwa Nabi Muhammad SAW ketika datang membacakan kitab suci Al-Qur'an maka orang-orang yang tidak memegang hawa dan ta'asub menyaksikan mereka akan kebenaran Nabi Muhammad SAW dan kebenaran Al-Qur'an. Akan tetapi ada juga orang yang tinggal dalam kesesatan, tidak mau mengakui kenabian Nabi Muhammad SAW dan kebenaran Al-Qur'an, mereka itu adalah orang-orang yang ta'ashub. Haji Abdul Karim Amrullah dalam menjelaskan orang ta'asub terebut dijelaskannya dengan menggunakan adagium yang berbunyi hawa pantang karandahan, napasu yang pantang kakurangan. ${ }^{69}$ Hawa pantang kerendahan, nasfu yang pantang kekurangan.

Arti dari adagium tersebut adalah gambaran bagi orang yang memperturutkan hawa nafsu. Hawa memiliki karakter pantang kerendahan, dan nafsu memiliki karakter pantang kekurangan. Dalam keseharian orang Minangkabau pepatah tersebut digunakan atau diucapkan kepada orang yang mudah tersinggung dan hanya memiliki benar sendiri dan tidak mau menerima masukan dan atau nasehat dari orang lain.

2) Adakah tumbuh rumput atau sayuran di bawah rumah

${ }^{69}$ Haji Abdul Karim Amrullah, al-Burhân, 119. 
Haji Abdul Karim Amrullah dalam tafsirnya al-Burbân tidak meninggalkan aspek lokal yang mengitarinya, betapa tidak dalam penjelasannya terkait penafsiran Qs. Ad-Dhuba, ia katakan bahwa tidak akan hidup manusia dan tumbuhan jika tidak ada pergantian siang dan malam, dan bahkan tumbuhan yang tidak melihat cahaya matahari dan bulan, padahal ia dikandung siang dan malam, juga tidak bisa hidup! Lihatlah adakah tumbuh rumput atau sayuran di bawah rumah? ${ }^{70}$

Pertanyaan yang dimunculkan oleh Haji Abdul Karim Amrullah merupakan gambaran rumah orang Minangkabau yang lantainya tinggi dari tanah dan memiliki ruang di bawah lantai rumah tersebut, jadi makna -adakah rumput atau sayuran tumbuh di bawah rumah- adalah di bawah lantai tersebut, yang tidak dapat masuk cahaya matahari dan cahaya bulan. Sehingga tidak bisa tumbuh rumput dan sayuran di bawah lantai rumah tersebut.

Analogi yang disampaikan Haji Abdul Karim tersebut memperlihatkan kondisi lokal orang Minangkabau yang memiliki rumah seperti rumah panggung. Yang di bawah lantai rumah tersebut ada ruang atau tanah, di dalamnya biasa ditempati oleh hewan peliharaan seperti itik, ayam dan sebagainya. Di samping menjelaskan keterangan ayat Allah betapa pentingnya ciptaan Allah (siang dan malam serta matahari) Haji Abdul Karim Amrullah juga mempromosikan gambaran rumah yang menjadi tempat tinggal orang Minangkabau dengan menyuruh memperhatikan bahwa rumah yang tidak terdapat satu tanaman pun hidup di dalamnya.

\section{b. Dalam al-Da'wah wa al-Irsyâd ilâ Sabîl al-Rasyâd}

Relasi yang telah dibangun antara Al-Qur'an dan adat Minangkabau yang melahirkan adagium ABS-SBK, meneguhkan bahwa tafsir Al-Qur'an yang ditulis oleh ulama Minangkabau, seperti Abdul Lathif Syakur ini, membuktikan bahwa untuk menjaga relasi antara Al-Qur'an dan masyarakat Minangkabau, maka ia elaborasi penafsirannya dengan menggunakan adagium-adagium yang relevan dengan ayat Al-Qur'an yang hendak ditafsirkannya. Adagium Minang merupakan salah satu unsur lokal yang meresapi tafsir Al-Qur'an yang ditulis oleh Abdul Lathif Syakur membuktikan bahwa relasi itu masih terjaga. Karena itu Al-Qur'an menjadi sesuatu yang hidup dan proaktif menjawab pelbagai persoalan yang ada $^{71}$ terutama bagi masyarakat Minangkabau. Maka untuk menjaga relasi antara budaya Minangkabau dengan Al-Qur'an berada pada wilayah interpretasi. Karena interpretasilah yang akan menjaga dan mengabadikan relasi antara budaya Minang

\footnotetext{
${ }^{70}$ Haji Abdul Karim Amrullah, al-Burbân, 24.

${ }^{71}$ Aksin Wijaya, Relasi Al-Qur'an dan Budaya Lokal (Sebuah Tatapan Epistemologis), Makalah, 8 .
} 
dengan agama Islam yang telah terpatri dalam adagium Adat Basandi Syarak, Syarak Basandi Kitabullah (ABS-SBK), Syarak Mangato Adat Mamakai.

Penulis menemukan adagium-adagium Minangkabau yang meresapi tafsir wa min al-Nâs sebagai bentuk dari perwujudan menjaga relasi Al-Qur'an dengan budaya Minangkabau, diantaranya adalah;

1) Papek di lua pancuang di dalam

Di antara adagium Minangkabau yang digunakan oleh Abdul Lathif Syakur untuk menjelaskan penafsirannya adalah papek dilua runciang di dalam. Adagium ini digunakannya untuk menjelaskan penafsiran Qs. Al-Baqarah/2:204206. Abdul Lathif Syakur menyebutkan bahwa ayat tersebut turun kepada Ubai gelarnya Akhnas, ia merupakan orang yang manis mulut sehingga Nabi SAW menyangka ia orang baik. Abdul Lathif Syakur dalam menjelaskan sifat Ubai tersebut menggunakan adagium Minangkabau yang menyatakan "papek dilua pancuang di dalam". ${ }^{72}$ Adagium tersebut menggambarkan sifat orang munafik yang memiliki makna mulutnya mukmin hatinya munafik, atau dalam ungkapan lain disebutkan lain dimulut, lain di hati.

Penggunaan adagium tersebut mendekatkan kepada pemahaman orang Minangkabau yang komunikasi sehari-hari sarat dengan pepatah dan adagiumadagium yang memiliki makna yang dalam. Jika ungkapan papek dilua pancuang di dalam telah diucapkan maka maknanya adalah orang munafik dan seumur hidup orang tidak akan percaya kepada orang yang memiliki sifat tersebut.

2) Adat lamo pusako usang

Adagium berikutnya yang digunakan oleh Abdul Althif Syakur dalam menjelaskan penafsiran adalah adat lamo pusako uasang. Adat lamo pusako usang artinya adalah sesuai dengan ketentuan yang berlaku ${ }^{73}$ yang menunjukkan kepedulian terhadap kelestarian adat Minangkabau hendaknya terwujud. Pepatah ini digunakan oleh Abdul Lathif Syakur untuk menunjukkan pembelaan orangorang yang tidak mau mengikuti apa yang telah Allah turunkan yakni Al-Qur'an, namun mereka membantah dengan mengatakan bahwa kami mengikuti apa yang telah diwariskan oleh bapak-bapak kami. Keterangan tersebut terdapat pada penjelasannya akan Qs. Luqman ayat 20-21. Abdul Lathif Syakur menggambarkan orang yang seperti dalam ayat tersebut, sikapnya apabila di ajak kepada agama Allah dengan ungkapan orang Minang yang mengatakan adat lamo pusako using, ${ }^{74}$ artinya apa yang dilakukan oleh al-Nadar bin Harits dan pengikutnya adalah

${ }^{72}$ Abdul Lathif Syakur, al-Da'wah... 9.

${ }^{73}$ Arriyanti, Estetika Pasambahan Pada Upacara Perkawinan di Kecamatan Banu Hampu Kabupaten Agam, Jurnal Madah, volume 6, nomor2. Edisi Oktober 2015. 127. Diakses pada hari senin 9 maret 2020 .

${ }^{74}$ Abdul Lathif Syakur, al-Da’wah... 23. 
mengikuti nenek moyang mereka, sama halnya kalau di Minangkabau dengan mengikuti niniak mamak yang telah terdahulu.

Adagium yang digunakan Abdul Lathif dalam menjelaskan penafsiran ayat tersebut, tersirat pesan secara halus kepada orang-orang Minangkabau yang mementingkan adat daripada agama. Penulis melihat bahwa harapan Abdul Lathif Syakur dibalik penyampaian adagium tersebut adalah orang-orang Minangkabau khususnya orang-orang Balai Guruh mau mengikuti dan mengamalkan ajaran Islam sebagaimana mestinya. Sebab tabiat juga bagi orang Minangkabau adalah dia tidak sudi dikatakan orang munafik dan apakah lagi disampaikan lewat adagium yang sudah jamak diketahui oleh orang Minang.

\section{Kesimpulan}

Penelitian ini menyimpulkan bahwa tafsir Al-Qur'an Minangkabau sarat akan serapan lokalitas, seperti yang ditemukan dalam tafsir al-Burbân karya Haji Abdul Karim Amrullah, Risâlah al-Qaul al-Bayân karya Syeikh Sulaiman Arrasuli, dan al-Da'wah wa al-Irsyâd ilâ sabîl al-Rasyâd karya Abdul Lathif Syakur. Penelitian ini telah membuktikan dan juga menguatkan pernyataan Anthoni A. Jhons dan Islah Gusmian yang keduanya berpandangan bahwa karya tafsir tidak bisa dipisahkan dari unsur lokalnya.

\section{Bibliografi}

Abrams, M.H. A Glossary of Literary Terms Seventh Edition, United States of Amerika, Publisher: Earl McPeek, 1999,

Anjela, Marisa dan Drs. H.M Razif, Pergeseran Peran Mamak Terhadap Kemenakan Dalam Adat Minangkabau Di Kanagarian Simalanggang (Kecamatan Payakumbuh Kabupaten 50 Kota) Jom FISIP Volume 1 No. 2 - Oktober 2014.

Arriyanti, Estetika Pasambahan Pada Upacara Perkawinan di Kecamatan Banu Hampu Kabupaten Agam, Jurnal Madah, volume 6, nomor2. Edisi Oktober 2015. Hal. 127. Diakses pada hari senin 9 maret 2020.

Al-Bukhari, Abu Abdullah Muhammad ibn Ismāil ibn Ibrāhỉm ibn al-Mughỉrah ibn Bardizbah al-Ju'fl, Shabỉh Bukhāri', al-Qōhirah: Dōr alHadit, $1425 \mathrm{H} / 20004$

al-Râzî, Fakhruddîn. Tafsir al-Kabîr wa Mafatih al-Ghaib, Libanon: Dâr al-Fikr, $1401 \mathrm{H} / 1981 \mathrm{M}$.

Amarullah, Haji Abdul Karim. al-Burân, Bukittinggi: Dar Fikr "Baru" Fort De Kock, 1927 
334 | AL QUDS : Jurnal Studi Alquran dan Hadis vol. 5, no 1, 2021

Arrasuli, Syeikh Sulaiman. pedoman Hidup di alam Minangkabau menurut garisan adat dan syarak, Bukittinggi: Tsamarah al-Ikwan, 1939. 1928

Risâlah al-Qaul al-Bayân fî Tafsîr al-Qur'ân, Bukittinggi: Fort de Kock, - Pertalian Adat \& Syara' (alih bahasa oleh Hamdan Izmy), Ciputat: Ciputat Press, 2003.

Baidan, Nasruddin. Perkembangan Tafsir Al-Quran di Indonesia, Tiga serangkai, 2002.

Bahary, Ansor. Tafsir Nusantara: Studi Kritis Terhadap Marah Labid Nawawi al Bantani, Jurnal Ulul Albab Volume 16, No.2 Tahun 2015.

Baidowi, Ahmad. “Aspek Lokalitas Tafsir al-Iklīl fì Ma'âni al-Tanzīll” dalam Jurnal NUN vol. 1, no. 12015

Cheng, Yin Cheong. Fostering Local Knowledge and Human development in Globalization of Education, The International Journal of Education Management, Volume 18 Number 1-2004. Pp 7-24 Cemerald Group Publishing Limited- ISSN 0951-354X DOI 10.1108/09513540410512109.

Cook, Phipip. Locality, Structure, and Agency: A Theoretical Analysis, Source: Cultural Anthropology, Vol. 5, No. 1 (Feb., 1990), pp. 3-15 Published by: Wiley on behalf of the American Anthropological Association Stable URL: https://www.jstor.org/stable/656501 Accessed: 07-02-2019 02:54 UTC.

Echols, John M. dan Hassan Shadily, Kamus Ingris Indonesia, Jakarta: PT Gramedia Pustaka, 2006, cetatakan ke-XXVIII

Fahmi, Izzul. Lokalitas Tafsir di Indonesia: Studi Corak Kebudayaan dalam kitab Tafsir al-Ibrīz, Tesis pada Pasca Sarjana Universitas Islam Negeri Sunan Ampel Surabaya, tahun 2017.

Federspiel, Howard M. Kajian al-Quran di Indonesia dari Mabmud Yunus hingga Quraish Shibab, Bandung: Mizan, 1994.

Gusmian, Islah. Tafsir al-Qur'an Bahasa Jawa Pengukuhan Identitas, ideology, dan Politik, Jurnal Subuf, Vol.9.No. 1., Jun 2016, hlm. 141-168. Issn 19796544: eISSN 2356-1610;http://jurnalsuhuf.kemenag.go.id.

- Tafsir al-Qur'an di Indonesia Sejarah dan Dinamika, Jurnal Nun, Vol. 1, No. 1, 2015,

Goldziher, Ignaz. Mazhab Tafsir dari Klasik hingga Modern (terj. M. Alaika Salamullah, dkk), Yogyakarta: Penerbit eLSAQ Press, Cetakan V, 2010

Gusmian, Islah. Khazanah Tafsir di Indonesia dar Hermeneutik hingga Ideologi, Jakarta: Teraju, 2003, 
Harder, Nelly van Doorn-, Southeast Asia dalam Andrew Rippin (ed) The Islamic World, London \& New York: Routledge, 2010.

Jhons, Anthony H. tentang Quranic Exegesis in Malay World: in Search of a frofile dalam Anrew Rippin, (ed), approach to the bistory of the interpretation of the Quran, Oxpord: Clarendon House, 1998. Lihat juga Hamka Hasan, Pemetaan tafsir di Indonesia (1990-2000) Jurnal Studi Alqur'an, Vol.I, No. 3, 2006,

M.S,Amir. Adat Minangkabau (Pola dan Tinjauan Hidup Orang Minangkabau), Jakarta: PT Mutiara Sumber Widya, 2003

Nazwar, Akhria. Syekh Ahmad Khatib Ilmuan Islam di Permulaan Abad Ini, Jakarta: Pustaka Panjimas, 1983

Nasrullah, Respons Dan Tantangan Kaum Tua Atas Kritik Kaum Muda Terhadap Tarekat Di Minangkabau Awal Abad 20, Jurnal 'Anil Islam Vol. 9. Nomor 2, Desember 2016.

Rohmana, Jajang A. Sejarah Tafsir al-Qur'an di Tatar Sunda, Bandung: Mujahid Press, 2017.

Saydam, Gouzali. Kamus Lengkap Bahasa Minang (Minang-Indonesia), Padang: PPIM Sumatera Barat, 2004

Sujarwa, Ilmu Sosial dan Budaya Dasar, Yogyakarta: Pustaka Pelajar., 2010

Syakur, Abdul Lathif. Al-Da'wah Wa Al-Irsyâd Ilâ Sabîl Al-Rasyâd, Bukittinggi: tsamarah al-Ikhwan, $1370 \mathrm{H} / 1951 \mathrm{M}$

Tim Penulis, Kamus Besar Bahasa Indonesia (Jakarta: Balai Pustaka,2002)

Usman, Abdul Kadir Dt. Yang Dipatuan, Kamus Umum Bahasa Minangkabau Indonesia, Padang: Angrek Media, 2002

Wahidi, Ridhoul. Tafsir Yâ Ayyuha a al-LaŻina âmanū Karya Syaikh Abdul Latif Syakur 1882-1963 (sunting teks dan analisis Isi), Penelitian Pascasarjana UIN Walisongo, tahun 2018.

Wijaya, Aksin. Relasi Al-Qur'an dan Budaya Lokal (Sebuah Tatapan Epistemologis), t.tp, t.th.

Yulika, Febri. Epistemologi Minangkabau; Makna Pengetahuan dalam Filsafat Adat Minangkabau, Padang Panjang: Institut seni Indonesia Padang Panjang, 2017

Yunus, Mahmud. Tafsir al-Quranul Karim, Jakarta:Pustaka Muhammadiyah, Cetakan ke VII, 1957. 
336 | AL QUDS : Jurnal Studi Alquran dan Hadis vol. 5, no 1, 2021

Zamakhsyarî, Abu al-Qâsim Muhammad Ibn Umar. al-Kasyâf an Haqâiq ghawâmidh al-Tan₹îl wa 'uyun al-Aqâwil fì wujūh al-Ta'wîl, Riyadh: Maktabah al-'abikân, $1418 \mathrm{H} / 1998$.

Zaiyadi, Ahmad. Dinamika Studi al-Qur'an di Indonesia, https://issuu.com/jurnalalbayanstiq/docs/1.zaiyadi, diakses pada tanggal $30 / 10 / 2018$. 